\title{
Activity-Based Protein Profiling of Retaining -Amylases in Complex Biological Samples
}

Chen, Yurong; Armstrong, Zachary; Artola, Marta; Florea, Bogdan I; Kuo, Chi-Lin; de Boer, Casper; Rasmussen, Mikkel S.; Abou Hachem, Maher ; van der Marel, Gijsbert A.; Codée, Jeroen D. C. Total number of authors: 13

Published in:

Journal of the American Chemical Society

Link to article, DOI:

10.1021/jacs.0c13059

Publication date:

2021

Document Version

Publisher's PDF, also known as Version of record

Link back to DTU Orbit

Citation (APA):

Chen, Y., Armstrong, Z., Artola, M., Florea, B. I., Kuo, C-L., de Boer, C., Rasmussen, M. S., Abou Hachem, M., van der Marel, G. A., Codée, J. D. C., Aerts, J. M. F. G., Davies, G. J., \& Overkleeft, H. S. (2021). Activity-Based Protein Profiling of Retaining -Amylases in Complex Biological Samples. Journal of the American Chemical Society, 143(5), 2423-2432. https://doi.org/10.1021/jacs.0c13059

\section{General rights}

Copyright and moral rights for the publications made accessible in the public portal are retained by the authors and/or other copyright owners and it is a condition of accessing publications that users recognise and abide by the legal requirements associated with these rights.

- Users may download and print one copy of any publication from the public portal for the purpose of private study or research.

- You may not further distribute the material or use it for any profit-making activity or commercial gain

- You may freely distribute the URL identifying the publication in the public portal 


\title{
Activity-Based Protein Profiling of Retaining $\alpha$-Amylases in Complex Biological Samples
}

\author{
Yurong Chen," Zachary Armstrong," Marta Artola, Bogdan I. Florea, Chi-Lin Kuo, Casper de Boer, \\ Mikkel S. Rasmussen, Maher Abou Hachem, Gijsbert A. van der Marel, Jeroen D. C. Codée, \\ Johannes M. F. G. Aerts, Gideon J. Davies,* and Herman S. Overkleeft*
}

Cite This: J. Am. Chem. Soc. 2021, 143, 2423-2432

Read Online

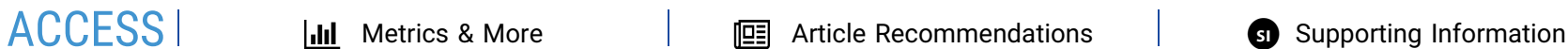

ABSTRACT: Amylases are key enzymes in the processing of starch in many kingdoms of life. They are important catalysts in industrial biotechnology where they are applied in, among others, food processing and the production of detergents. In man amylases are the first enzymes in the digestion of starch to glucose and arguably also the preferred target in therapeutic strategies aimed at

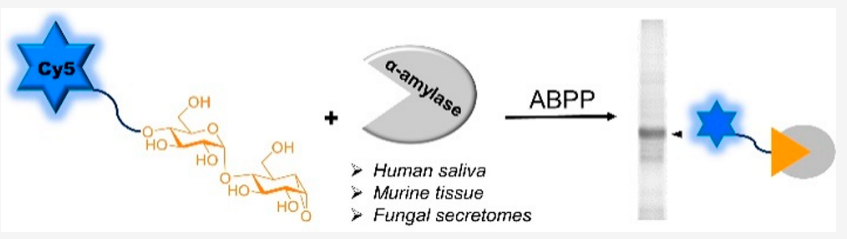
the treatment of type 2 diabetes patients through down-tuning glucose assimilation. Efficient and sensitive assays that report selectively on retaining amylase activities irrespective of the nature and complexity of the biomaterial studied are of great value both in finding new and effective human amylase inhibitors and in the discovery of new microbial amylases with potentially advantageous features for biotechnological application. Activity-based protein profiling $(\mathrm{ABPP})$ of retaining glycosidases is inherently suited for the development of such an assay format. We here report on the design and synthesis of 1,6-epi-cyclophellitol-based pseudodisaccharides equipped with a suite of reporter entities and their use in ABPP of retaining amylases from human saliva, murine tissue as well as secretomes from fungi grown on starch. The activity and efficiency of the inhibitors and probes are substantiated by extensive biochemical analysis, and the selectivity for amylases over related retaining endoglycosidases is validated by structural studies.

\section{INTRODUCTION}

Retaining $\alpha$-amylases, belonging to the glycoside hydrolase (GH) 13 family (www.cazy.org), ${ }^{1}$ are starch-processing enzymes present in plants, animals, and microorganisms. ${ }^{2-4}$ They catalyze the hydrolysis of internal $\alpha$-1,4-glycosidic linkages in starch and related polysaccharides through a twostep Koshland double displacement mechanism (Figure S2A). In this mechanism, the aglycon is protonated by the general acid/base residue, followed by $S_{N} 2$ nucleophilic attack by the catalytic nucleophile at the anomeric center to form a covalent enzyme-substrate intermediate with inversion of anomeric configuration. The covalent enzyme-substrate adduct is subsequently hydrolyzed to yield oligosaccharide products (for instance linear and $\alpha$-1,6-branched malto-oligosaccharides) with net retention of $\alpha$-anomeric configuration. ${ }^{5}$

Starch is the main product of major human and animal feedstock crops including wheat, rice, maize, tapioca, and potato. Traditionally, large-scale starch processing, an industry established over 100 years ago, relied on the degradation of starch by acid hydrolysis. ${ }^{6,7}$ Amylases have gained considerable traction as alternatives to conventional chemical starch hydrolysis, as they are more environmentally benign, are less energy intensive, and moreover may produce more defined oligosaccharide products from starch polymers. ${ }^{8,9}$ Today, a large number of $\alpha$-amylases from microbial sources are commercially available and are widely used for the production of high glucose and fructose syrups. ${ }^{10,11}$ Another major application of $\alpha$-amylases is found in the detergent industry, where they act at low temperatures and alkaline $\mathrm{pH}$ to remove tough starch stains from clothes and porcelains under mild conditions. $^{12} \alpha$-Amylases are furthermore extensively employed in textile, food, paper, and biofuel industries. The $\alpha$ amylases currently applied in industrial biotechnology originate from a limited number of fungal and bacterial strains, including Aspergillus oryzae and Bacillus licheniformis. ${ }^{11,13}$ The microbial world however may harbor many additional $\alpha$-amylases including ones that differ functionally in terms of activity, substrate specificity, and resistance to (harsh) biotechnological conditions.

In addition to their potential in biotechnological applications, $\alpha$-amylases have received increased interest in the past decades in the context of human health. In mammals, digestion of starch by salivary and pancreatic $\alpha$-amylases leads to linear and branched malto-oligosaccharides. These are largely hydrolyzed to glucose by $\alpha$-glucosidases located in the intestinal

Received: December 17, 2020

Published: January 26, 2021 
mucosa, which then enters the bloodstream by means of facilitated diffusion. Control of postprandial glucose levels, which has proven to be a key factor for the treatment of diabetes and obesity, ${ }^{14}$ might be achieved by activity modulation of starch-processing enzymes. Antidiabetic drugs currently used in the clinic include the $\alpha$-glucosidase inhibitors, ${ }^{15,16}$ miglitol, voglibose, and acarbose, the last of which also inhibits human pancreatic $\alpha$-amylase (HPA). ${ }^{17,18}$ However, their effectiveness is offset by undesirable side effects, including diarrhea, flatulence, and abdominal pain, secondary effects that arise predominantly from inhibition of intestinal $\alpha$-glucosidases. Hence, selective inhibitors targeting exclusively HPA, the first enzyme in the digestion sequence, would be of great interest. ${ }^{19-24}$

Activity-based protein profiling (ABPP) has emerged as a powerful strategy to obtain qualitative and quantitative activity information on enzymes of interest in complex mixtures. ${ }^{25,26}$ $\mathrm{ABPP}$ is especially useful for retaining glycosidases that form a covalent enzyme-substrate intermediate during hydrolysis. It relies on the availability of suitable activity-based probes (ABPs) that are generally generated from covalent and irreversible inhibitors by equipping these with a reporter entity (a fluorophore or biotin) or a bio-orthogonal tag. By means of $\mathrm{ABPP}$, enzyme activities can be rapidly identified and quantified (comparative ABPP) and the effect of inhibitors on target enzymes studied in cell extracts and living cells (competitive ABPP). Our work on retaining glycosidase ABPP is rooted in the known mechanism-based $\beta$-glucosidase inhibitor cyclophellitol, isolated from Phellinus sp. ${ }^{27}$ In the first instance we applied cyclophellitol-derived ABPs to the study of retaining exo-acting $\alpha$ - and $\beta$-glycosidases. ${ }^{28-32}$ More recently, we expanded the methodology toward retaining endoglycosidases in our work on xylobiose-configured ABPs to investigate endo-acting xylanases in Aspergillus secretomes. ${ }^{33,34}$ Here, we reveal the efficacy of retaining glycosidase ABPP by the design and chemical synthesis of a panel of maltobiose epicyclophellitol derived retaining $\alpha$-amylase inhibitors and ABPs, the kinetic and structural analysis of their interactions with microbial $\alpha$-amylases, and the application of these probes for rapid detection and identification of $\alpha$-amylases in fungal secretomes, mouse tissue, and human saliva. Our work complements a recent ${ }^{24}$ study by Withers and colleagues, who reported a chemoenzymatic synthesis of maltobiose epicyclophellitol, to which we could match our chemically derived material and as well our structural work on $\alpha$-amylase-inhibitor complexes. Our results moreover illustrate the potential of retaining $\alpha$-amylase ABPP in the annotation of $\alpha$-amylases in complex biological samples.

\section{RESULTS AND DISCUSSION}

Design and Synthesis of $\alpha$-Amylase Inhibitors and Activity-Based Probes. We have previously revealed that 1,6-epi-cyclophellitol and its aziridine and cyclic sulfate analogues (Figure 1A) are potent mechanism-based $\alpha$ glucosidase inhibitors and that their tagged versions are effective activity-based retaining $\alpha$-exoglucosidase probes. ${ }^{30,35}$ These monosaccharidic cyclitols however do not inhibit endoacting $\alpha$-amylases, which we argued is because of the absence of productive binding with the larger endo-glycosidase active sites (Figure S2C). In line with this consideration, Withers and co-workers subsequently reported that the maltose disaccharide mimetic $\alpha$-1,4-glucopyranosyl epi-cyclophellitol (compound 1a, Figure 1B), which they prepared by enzymatic $\alpha$ -
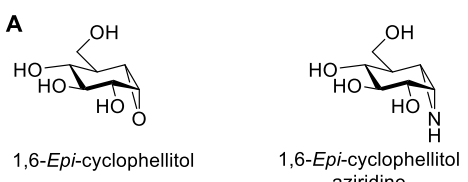

1,6-Epi-cyclophe
aziridine

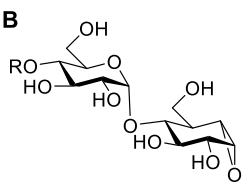

$\begin{aligned} \text { 1a } \mathrm{R} & =\mathrm{H} \\ \text { 1b } \mathrm{R} & =-\left(\mathrm{CH}_{2}\right)_{8} \mathrm{NH}_{2} \\ \text { 1c } \mathrm{R} & =\mathrm{Cy} 5\end{aligned}$

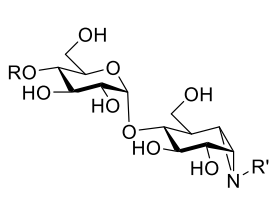

2a R $=\mathrm{H}_{1} \mathrm{R}^{\prime}=-\left(\mathrm{CH}_{2}\right)_{8} \mathrm{NH}_{2}$ 2b R $=H, R^{\prime}=$ Cy 5 2c R = Et, $R^{\prime}=$ Cy5

$1 \mathrm{~d} R=$ biotin

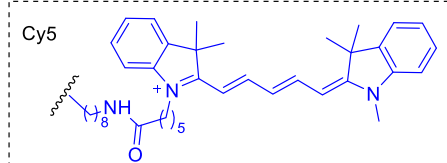

biotin

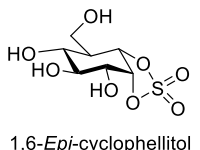

cyclosulfate

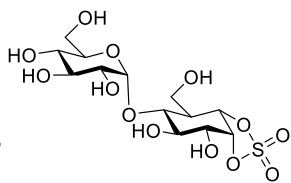

$3 a$

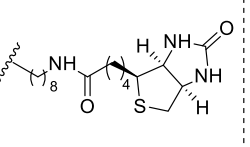

Figure 1. Design of mechanism-based retaining $\alpha$-glucosidase inhibitors and ABPs: (A) structures of retaining $\alpha$-exoglucosidase inhibitors; (B) structures of retaining $\alpha$-endoglucosidase inhibitors and ABPs, which are subject of the here-described studies.

glucosylation of 1,6-epi-cyclophellitol, is an effective mechanism-based, covalent, and irreversible HPA inhibitor. ${ }^{24}$ Crystallographic analysis of an HPA-inhibitor complex points to the $\mathrm{O}^{\prime}$ of the nonreducing end sugar, which may simply be alkylated to block potential exoglycosidase action as a promising site for orthogonal functionalization (as in $\mathbf{1 b}$ ) to allow introduction of a reporter entity (a fluorophore or biotin, as in $1 \mathrm{c}$ and $1 \mathrm{~d}$ ). Alternatively and in line with our previous ${ }^{33}$ work on xylanase ABPs, we envisaged the design of maltoseconfigured cyclophellitol aziridines bearing the reporter tag on the aziridine nitrogen, either with or without an $\mathrm{O}^{\prime}$ cap (compounds 2a-2c, Figure 1B). Finally and in line with our previous results on 1,6-epi-cyclophellitol cyclosulfate being a potent and selective retaining $\alpha$-exoglucosidase inhibitor, ${ }^{30,35}$ we decided to produce the corresponding maltose cyclosulfate (compound 3a, Figure 1B) as well with the aim to investigate whether this Michaelis complex emulating inhibitor would also act on amylases.

We have recently reported the synthesis of xylobiosecyclophellitols via the direct glycosylation of $x y l o$-cyclophellitol (aziridine) acceptors. ${ }^{33}$ This route however appeared not feasible for the construction of compounds $1 \mathbf{a}-\mathbf{d}$ since the epoxide functionality in partially protected 1,6-epi-cyclophellitols proved unstable toward stoichiometric amounts of Lewis acid under the conditions required to effect formation of $\alpha$-1,4-glycosidic bonds using contemporary glycosylation conditions. Alternatively, cyclohexene $\mathbf{5}$ was found to readily undergo glycosylation with imidate donor 4a under $\mathrm{N}, \mathrm{N}$ dimethylformamide (DMF) and trifluoromethanesulfonic acid (TfOH) activating conditions, affording pseudodisaccharide $\mathbf{6 a}$ in good yield. ${ }^{36}$ Selective deprotection of the 4-methoxybenzyl group in 6 a followed by epoxidation afforded an inseparable mixture of $\alpha / \beta$-epoxides in a 1:3 ratio, which were silylated and separated by silica gel column chromatography to yield pure $\mathbf{8 a}$ and 9a. Desilylation and global debenzylation of $8 \mathbf{a}$ by Pearlman's catalyst hydrogenation gave maltobiose epi-cyclophellitol 1a, of which all analytical and spectroscopical data proved to match those of the chemoenzymatically produced compound. $^{24}$ The epoxide in 9 a was converted to aziridine 14a by treatment with sodium azide followed by a Staudinger-type 
Scheme 1. Synthesis of the Inhibitors and ABPs Subject of the Here-Described Studies ${ }^{a}$
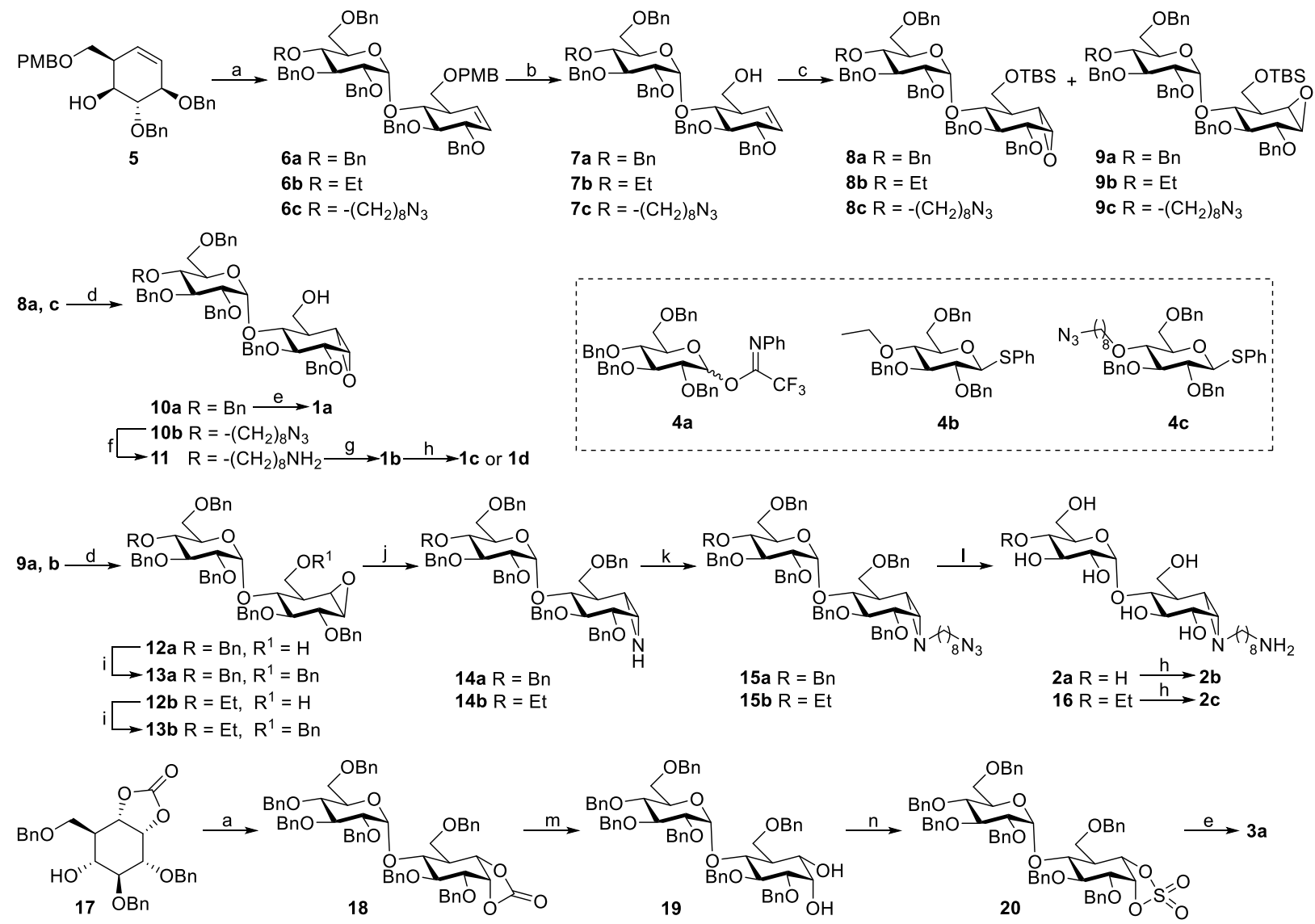

${ }^{a}$ Reagents and conditions. (a) For $6 \mathbf{a}$ and 18: 4a, TfOH (1.5 equiv), DMF, DCM, $4 \AA$ molecular sieves, -20 to $0{ }^{\circ} \mathrm{C}, 6 \mathbf{a} 96 \%, 1857 \%$. For $6 \mathbf{b}: 4 \mathbf{b}$, NIS, TfOH (1.5 equiv), DMF, DCM, 4 Å molecular sieves, $0{ }^{\circ} \mathrm{C}, 88 \%$. For $6 \mathrm{c}: 4 \mathrm{c}$, NIS, TfOH (1.5 equiv), DMF, DCM, $4 \AA$ molecular sieves, $0{ }^{\circ} \mathrm{C}$, 87\%. (b) DDQ DCM $/ \mathrm{H}_{2} \mathrm{O}$ (19/1), rt, 7a 80\%, 7b 74\%, 7c 71\%; (c) (i) $m$ CPBA, DCM, $0{ }^{\circ} \mathrm{C}$ to rt; (ii) TBSCl, DMAP, imidazole, DCM, rt, 8a 20\%, 9a 58\%, 8b 21\%, 9b 65\%, 8c 22\%, 9c 63\%; (d) TBAF, THF, rt, 10a 90\%, 10b 87\%, 12a 91\%, 12b 88\%; (e) $\mathrm{Pd}(\mathrm{OH})_{2} / \mathrm{C}, \mathrm{H}_{2}, \mathrm{MeOH} / \mathrm{H}_{2} \mathrm{O} /$ dioxane (2/1/2), rt, 1a 100\%, 3a 89\%; (f) polymer-bound $\mathrm{PPh}_{3}, \mathrm{MeCN}, \mathrm{H}_{2} \mathrm{O}, 70{ }^{\circ} \mathrm{C}, 79 \%$; $(\mathrm{g}) \mathrm{Pd}(\mathrm{OH})_{2} / \mathrm{C}, \mathrm{H}_{2}, \mathrm{HOAc},{ }^{t} \mathrm{BuOH} / \mathrm{H}_{2} \mathrm{O} /$ dioxane (1/2/1), rt, 91\%; (h) Cy5-OSu or biotin-OSu, DIPEA, DMF, rt, 1c 33\%, 1d 16\%, 2b 10\%, 2c 17\%; (i) BnBr, NaH, TBAI, DMF, $0{ }^{\circ} \mathrm{C}$ to rt, $13 \mathbf{a}$ 82\%, 13b 75\%; (j) (i) $\mathrm{NaN}_{3}, \mathrm{LiClO}_{4}, \mathrm{DMF}, 100{ }^{\circ} \mathrm{C}$; (ii) polymer-bound $\mathrm{PPh}_{3}, \mathrm{MeCN}, 60{ }^{\circ} \mathrm{C}, 14 \mathrm{a} 48 \%, 14 \mathrm{~b} 42 \%$; (k) 8azidooctyltrifluoromethanesulfonate, DIPEA, DCM, $0{ }^{\circ} \mathrm{C}$ to rt, 15a $90 \%, \mathbf{1 5 b} 88 \%$; (l) Na, $\mathrm{NH}_{3}$ (liq.), ${ }^{t} \mathrm{BuOH}, \mathrm{THF},-60{ }^{\circ} \mathrm{C}, 2 \mathrm{a} 79 \%, 16$ 94\%; (m) NaOMe, DCM/MeOH (1/1), rt, 93\%; (n) (i) $\mathrm{SOCl}_{2}$, TEA, DCM, $0{ }^{\circ} \mathrm{C}$; (ii) $\mathrm{RuCl}_{3} \cdot 3 \mathrm{H}_{2} \mathrm{O}, \mathrm{NaIO}_{4}, \mathrm{EtOAc}_{\mathrm{ACN}} / \mathrm{H}_{2} \mathrm{O}(2 / 2 / 1), 0{ }^{\circ} \mathrm{C}$, $58 \%$.

ring closure. Alkylation and global deprotection of 14a under Birch conditions afforded alkyl-aziridine $2 \mathbf{a}$, which was equipped with a $\mathrm{Cy} 5$ fluorophore to produce ABP $\mathbf{2 b}$ (Scheme 1).

Our previous studies on endo-xylanases revealed that the xylobiose-cyclophellitol aziridine probe was susceptible to hydrolysis by exo-xylosidases present in Aspergillus secretomes. ${ }^{33}$ Thus, we hypothesized that "capping" the O4' position of maltobiose epi-cyclophellitol azirines with an ethyl group would prevent cleavage by exo-acting $\alpha$-glucosidases in complex biological samples. This was achieved by using $\mathrm{O} 4$ ethyl capped thiophenyl donor $\mathbf{4 b}$ for glycosylation with acceptor 5 under $N$-iodosuccinimide (NIS)/DMF/TfOH catalysis, giving $4^{\prime}$-ethyl pseudodisaccharide $\mathbf{6 b}$ in good yield. Following the same route as for $2 \mathrm{a}, 4^{\prime}$-ethyl capped maltobiose epi-cyclophellitol aziridine 16 could be readily obtained from intermediate $9 \mathrm{~b}$, which was equipped with a $\mathrm{Cy} 5$ fluorophore to produce $A B P$ 2c. We constructed epoxide-based ABPs by using thiophenyl donor $\mathbf{4 c}$, where the azidooctyl group was introduced in an early stage for later installation of reporter entities and also to prevent exo-glycosidase processing.
Following the established route, epoxide $\mathbf{1 b}$ was obtained after desilylation, azide reduction, and debenzylation of $\mathbf{8 c}$. Following coupling with a $\mathrm{Cy} 5$ fluorophore or biotin moiety, ABPs 1c and 1d were obtained, respectively.

The same strategy was also applied to construct maltobiose epi-cyclophellitol cyclosulfate 3a. Carbonate acceptor 17 was readily glycosylated with donor $4 a$ under $\mathrm{TfOH} / \mathrm{DMF}$ conditions, giving pseudodisaccharide $\mathbf{1 8}$ in moderate yield. Treatment of 18 with sodium methoxide gave diol 19. Generation of the cyclosulfite using thionyl chloride and subsequent oxidation gave perbenzylated cyclosulfate 20, the benzyl ethers of which were removed by Pearlman's catalyst hydrogenation to afford inhibitor 3a.

Kinetic Studies for Time-Dependent Inhibition of Aspergillus oryzae $\alpha$-Amylase by Maltobiose Inhibitors. To assess the potency of the synthesized maltobiose epicyclophellitols, we monitored the time-dependent inhibition of Aspergillus oryzae $\alpha$-amylase (hereafter termed as Takaamylase). Taka-amylase, one of the earliest amylases to be characterized and used commercially, ${ }^{37,38}$ is a retaining $\alpha$ amylase belonging to the GH13 subfamily 1 . This enzyme uses 
a pair of catalytic active site residues (Asp206 as a nucleophile and Glu230 as the acid/base) to cleave amylose chains and requires several subsites to be occupied to catalyze hydrolysis at meaningful rates. ${ }^{39}$

To assess time-dependent inhibition, the hydrolysis of 2chloro-4-nitrophenyl maltotrioside (CNP-M3) by Takaamylase was measured after preincubation with $2 \mathrm{mM}$ of inhibitors 1a, 1b, 2a, and 3a. All four inhibitors displayed a time-dependent inhibition of Taka-amylase; however the rates of inhibition varied greatly (Figure 2). Both the epi-

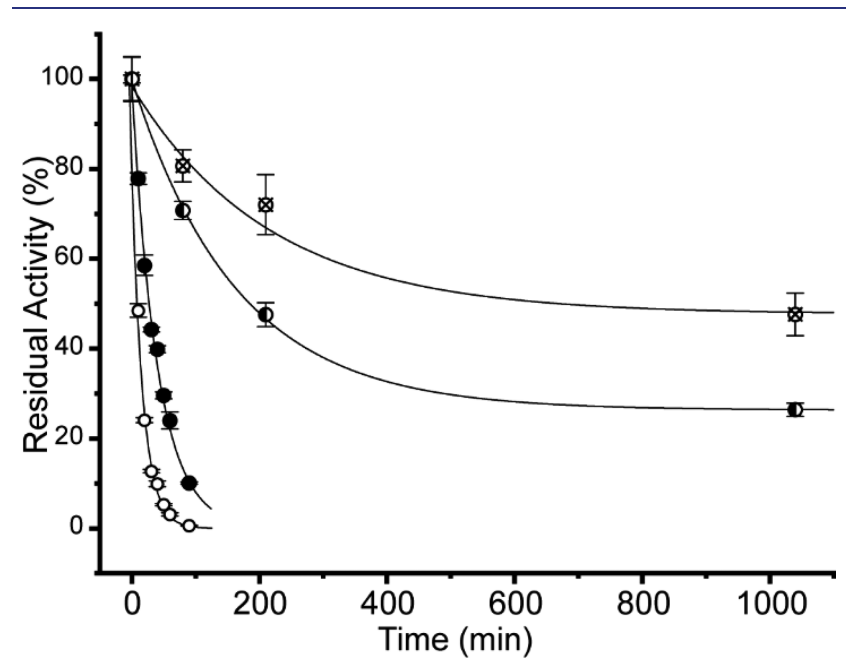

Figure 2. Time-dependent inactivation of Taka-amylase. Residual activity of Taka-amylase incubated with $2 \mathrm{mM}$ of either $\mathbf{1 a}(\mathbf{D}), \mathbf{1 b}$ $(0)$, 2a $(\otimes)$, or 3a $(\bullet)$ was assayed over time and fit to an exponential decay curve.

cyclophellitol epoxide 1a and aziridine 2a had slow rates of inactivation, with rate constants of $0.0061 \pm 0.0002 \mathrm{~min}^{-1}$ and $0.005 \pm 0.002 \mathrm{~min}^{-1}$, respectively. The rate constant for the inactivation by $\mathbf{1 a}$ is somewhat higher than was previously observed for its inhibition of HPA, determined to be 0.001 $\mathrm{min}^{-1}$ at a higher concentration of inhibitor $(3.6 \mathrm{mM}) .^{24} \mathrm{It}$ is somewhat surprising that the aziridine had a rate of inhibition slightly worse than that of the epoxide, as our previous work has demonstrated aziridine based inhibitors to be more potent for $\alpha$-glucosidases. ${ }^{30} \mathrm{We}$ speculate that $\mathrm{N}$-alkylation of the aziridine may reduce the initial binding of inhibitor $\mathbf{2 a}$, consequently reducing inactivation rates. Inhibition by the cyclosulfate inhibitor 3a was 4 - to 5-fold faster (rate constant = $0.0250 \pm 0.0009 \mathrm{~min}^{-1}$ ) when compared to $1 \mathrm{a}$ or $2 \mathrm{a}$. This observation agrees well with our previous work, which showed that the monosaccharide epi-cyclophellitol cyclosulfate was indeed the most potent cyclophellitol type inhibitor of recombinant lysosomal acid $\alpha$-glucosidase. ${ }^{35}$ Surprisingly, $4^{\prime}$ alkylamine $\mathbf{1 b}$ proved to be the most effective inhibitor tested, with an inhibition rate constant that was nearly 10 times that of the untagged 1a (rate constant $=0.057 \pm 0.003 \mathrm{~min}^{-1}$ ). This suggests that initial binding of $\mathbf{1 b}$ is aided by interactions between the -3 subsite and the $4^{\prime}$-alkylamine present, which in turn increases the rate of inhibition. Previous kinetic analysis of Taka-amylase catalytic rates has shown dramatic rate increases for the hydrolysis of a maltotetrasaccharide over a maltotrioside, ${ }^{39}$ highlighting the importance of binding in the -3 position with a natural substrate.

Structural Analysis of Inhibitor-Enzyme Complexes. We next sought to use X-ray crystallography to further understand the binding of inhibitors $\mathbf{1 a}, \mathbf{1} \mathbf{b}, \mathbf{2} \mathbf{a}$, and $\mathbf{3 a}$ to the active site of Taka-amylase. All four inhibitors formed covalent complexes with Taka-amylase, solved with resolution between 1.67 and $1.35 \AA$, and were covalently linked to the enzyme through the catalytic nucleophile Asp206 (Figure 3). The slow reaction rates necessitated prolonged incubation of the inhibitors with preformed crystals. The epi-cyclophellitol epoxides were soaked for 3 days. At this stage 1a reached $80 \%$ active site occupancy, while $\mathbf{1 b}$ had complete occupancy, reflective of its increased rate constant of inhibition when compared to 1a. After a week-long soak with 2a Taka-amylase crystals had approximately $70 \%$ inhibitor occupancy; thus soak length for this compound was further extended to 1 month after which complete occupancy was observed. The soak with 3a was also extended to 1 month to allow for complete active site occupancy.

The crystal structure of $\mathbf{1 a}$ bound to the active site nucleophile (Asp206) showed the cyclitol moiety to adopt a ${ }^{4} \mathrm{C}_{1}$ chair conformation, which is also observed for $\mathbf{1 b}$ and $\mathbf{3 a}$. This conformation matches that observed for the -1 sugar by Caner et al. ${ }^{24}$ for the binding of enzymatically synthesized 1a to HPA and the conformation of an in situ generated 5-fluoroidose trisaccharide, also to HPA. ${ }^{23}$ Although a detailed computational analysis of the conformational itineraries for a GH13 $\alpha$-amylase has yet to be done, a detailed analysis of a homologous GH13 amylosucrase from Neisseria polysaccharea has been published. ${ }^{40}$ This analysis proposes a ${ }^{4} \mathrm{C}_{1} \rightarrow\left[{ }^{3} \mathrm{H}_{4}\right]^{\ddagger}$ $\rightarrow{ }^{4} \mathrm{C}_{1}$ trajectory for the glycosylation step, consistent with the observed conformation of the inhibitor bound in the -1 position. The nucleophile, Asp206, in the 1a complex structure is present in two conformations, one minor unbound conformation which aligns with the uncomplexed form (PDB code 6YQ7) and the other rotated approximately $120^{\circ}$ from the uncomplexed orientation that we ascribe to the conformation present in the covalently inhibited enzyme (Figure 3, panel A, PDB code 6YQ9). This second conformation is also seen for the $\mathbf{1 b}$ complex which is at full occupancy. Bound 1a also forms nine direct hydrogen bonds with Taka-amylase (with His122, Arg204, Thr207, His296, and Asp297 in the -1 subsite and Trp83, Asp340, and Arg344 in the -2 subsite), replicating those seen in the structure of a complex between Taka-amylase and acarbose (PDB code 7TAA), with the exception of the hydrogen bond between the 6-OH of 1a and Thr207, and the lack of an H-bond with the catalytic nucleophile that is observed for acarbose. ${ }^{41}$

The structure of $4^{\prime}$-alkylamine epi-cyclophellitol $\mathbf{1 b}$ bound in the active site (Figure 3, panel B, PDB code 6YQC) maintains an identical hydrogen bonding network to that seen in the complex with 1a, the only difference being the complete occupancy of the inhibitor, resulting in the absence of an unbound Asp206 conformer and the presence of an alkyl tail. The $4^{\prime}$ tail of $\mathbf{1 b}$ can only be modeled to the sixth carbon (away from the maltose core) indicating that the terminal amine may form multiple interactions in the -3 subsite. The portion of the alkyl tail that could be modeled with confidence is appropriately positioned to form a $\mathrm{C}-\mathrm{H} / \pi$ hydrogen bond through the second carbon which is $3.9 \AA$ away from Tyr75. This interaction may in part be responsible for better binding of $\mathbf{1 b}$ to Taka-amylase and the resulting increased rate of inhibition.

The structure of the epi-cyclophellitol cyclosulfate $3 a$ complex has many similarities with complexes of the epoxide inhibitors $\mathbf{1 a}$ and $\mathbf{1 b}$ (Figure 3, panel C, PDB code 6YQB). 


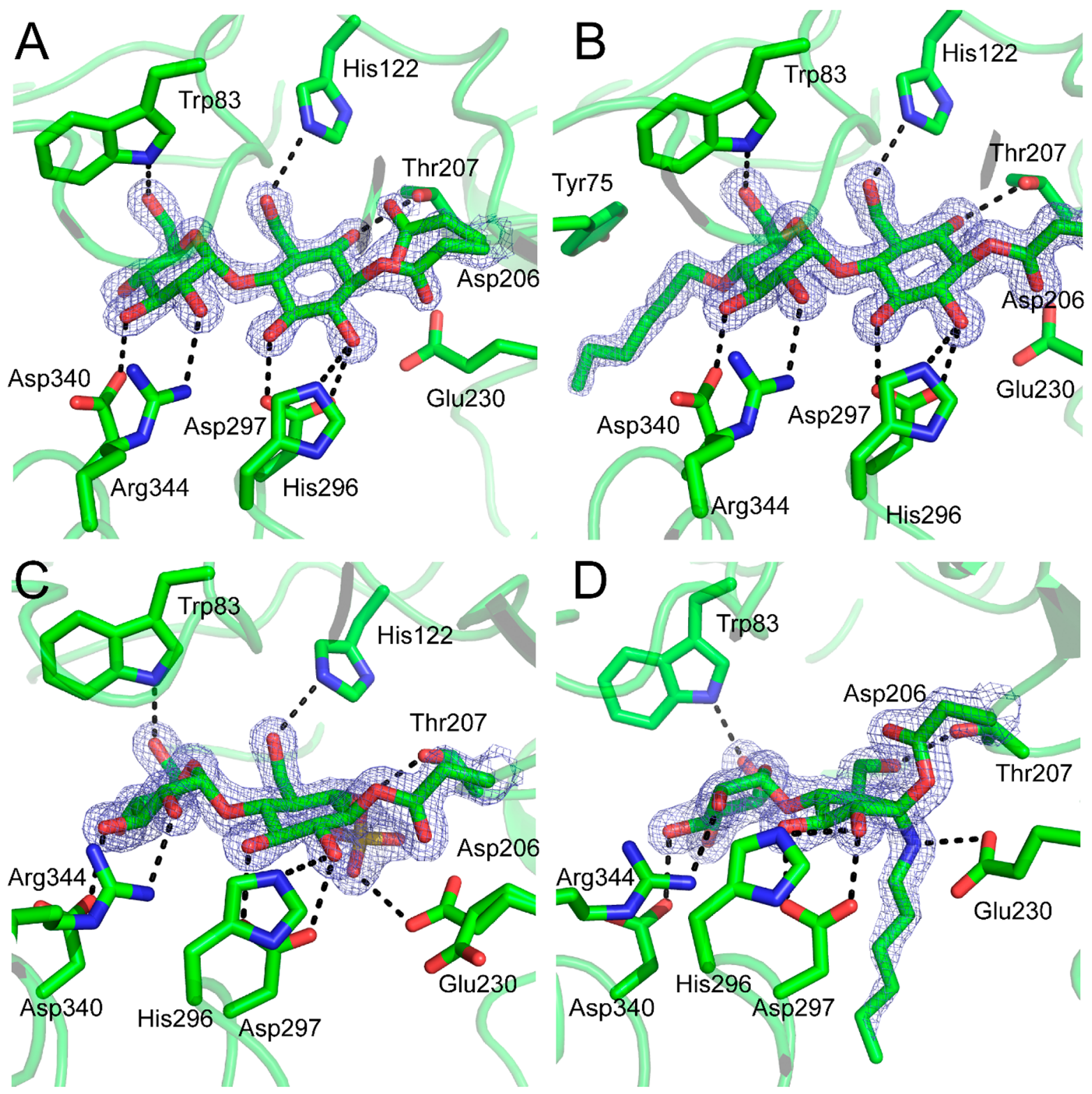

Figure 3. Covalent inhibition of Taka-amylase with glycosylated cyclophellitols. Crystal structures are shown between Taka-amylase and each of 1a (A), $\mathbf{1 b}(\mathrm{B}), 3 \mathbf{a}(\mathrm{C})$, and $\mathbf{2 a}(\mathrm{D})$. Electron density $\left(2 F_{\mathrm{o}}-F_{\mathrm{c}}\right)$ is shown for both the ligand and the catalytic nucleophile (Asp206) as a blue mesh contoured at $1.5 \sigma\left(\mathbf{1 a}=0.59 \mathrm{e}^{-} / \AA^{3}, \mathbf{1 b}=0.61 \mathrm{e}^{-} / \AA^{3}, 2 \mathrm{a}=0.46 \mathrm{e}^{-} / \AA^{3}, 3 \mathrm{a}=0.54 \mathrm{e}^{-} / \AA^{3}\right)$. The polypeptide is shown in cartoon form with active site residues shown as sticks. Apparent hydrogen bonding interactions are shown as dotted black lines. Active-site residue Arg204 is omitted for clarity.

The cyclitol is covalently attached to Asp206, again rotated approximately $120^{\circ}$ from the unreacted enzyme, and is in a ${ }^{4} \mathrm{C}_{1}$ conformation. The -2 sugar is positioned exactly as for $\mathbf{1 a}$, however the presence of an exocyclic sulfur at the 6 position has resulted in Thr207 being positioned within hydrogen bonding distance to the $\mathrm{O} 6$ that forms the sulfate ester. The sulfate group is also positioned within hydrogen bonding distance to the acid base residue, Glu230; however this residue appears in two different conformations in the structure.

Binding of $2 \mathrm{a}$ to Taka-amylase is strikingly dissimilar to the other three inhibitor complexes (Figure 3, panel D, PDB code 6YQA). The inhibitor is again covalently bound to Asp206; however the nucleophile is rotated nearly $180^{\circ}$ when compared to the other three complexes such that the nonbonded $\delta \mathrm{O}$ is positioned above the " $\beta$ " face of the bound cyclitol ring rather than below it. The hydrogen bonds between the inhibitor and the enzyme -1 subsite are also altered, with the cyclitol methoxy alcohol rotated to form a hydrogen bond with Thr207 (instead of His122), and the C6 nitrogen forms a hydrogen bond with the acid/base residue (Glu230). Furthermore, the reacted cyclitol, rather than ${ }^{4} \mathrm{C}_{1}$, is in an unprecedented $\mathrm{E}_{3}$ conformation, the emergence of which we attribute to the presence of the alkyl-chain. We have observed that cyclophellitol aziridines with $\mathrm{N}$-alkylation are generally well accepted in both exo-acting enzymes as these often have open + subsites $^{28-32}$ and endo-acting enzymes that target $\beta$ linkages, ${ }^{33}$ which typically contain long, tunnel, or groove-like active sites. The active site of Taka-amylase, conversely, is a Vshaped surface depression with a severe angle between the -1 and +1 sugar binding sites; this in turn constrains the conformation of the aziridine alkylation and the conformation of the cyclitol ring.

In Vitro Labeling of Recombinant Human Saliva $\alpha$ Amylase with ABPs 1c, 2b, and 2c. With the fluorescent 
A

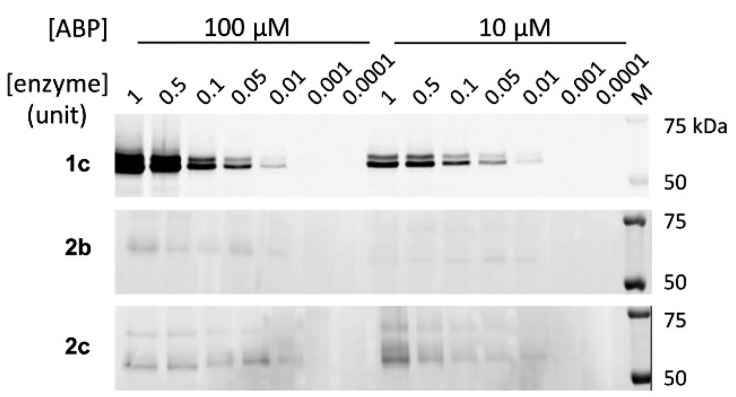

B

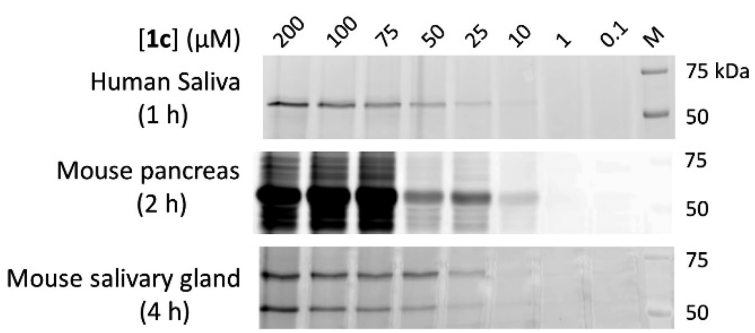

C

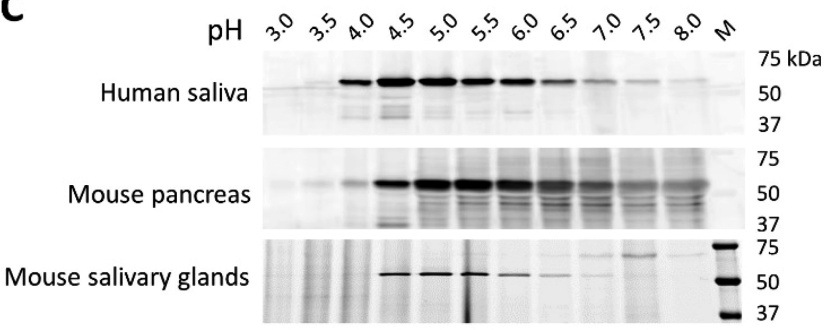

D

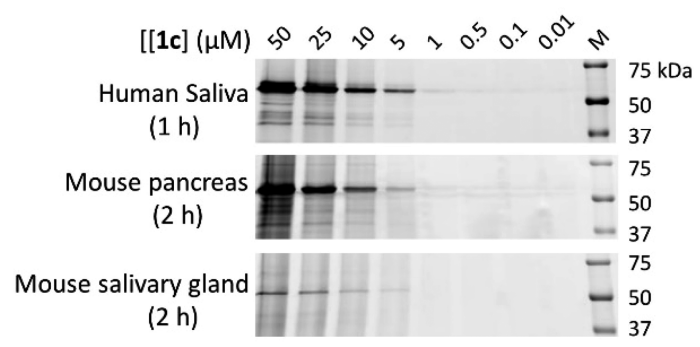

E

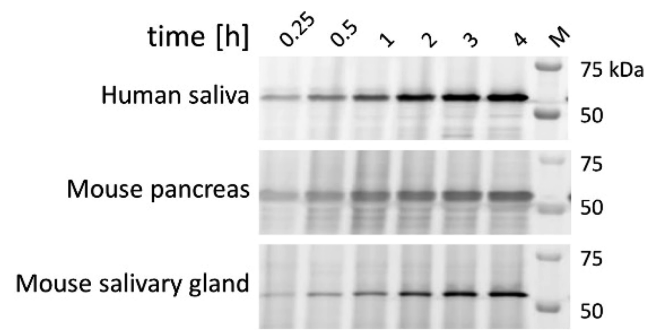

F

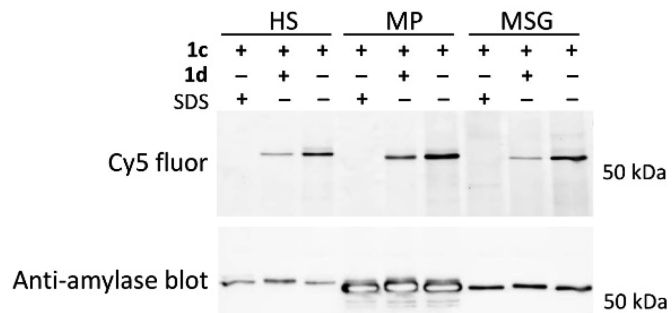

Figure 4. (A) Fluorescent labeling of recombinant human saliva $\alpha$-amylase (type XIII-A) with ABPs $\mathbf{1 c}, \mathbf{2 b}$, and $2 \mathrm{c}$ at $\mathrm{pH} 7$ after $1 \mathrm{~h}$ incubation at $37^{\circ} \mathrm{C}$. (B) Fluorescent labeling of concentrated human saliva, mouse pancreas, and salivary gland lysates $(55 \mu \mathrm{g}$ total protein) with different concentrations of $\mathrm{ABP} 1 \mathrm{c}\left(\mathrm{pH} 7.0,37^{\circ} \mathrm{C}\right)$. (C) $\mathrm{pH}$-dependent labeling with $\mathrm{ABP}$ 1c in complex biological samples. The optimal $\mathrm{pH}$ is approximately 5.0 in these three samples. (D) Detection limit of $\alpha$-amylase in complex biological samples labeled with ABP 1c ( $\left.\mathrm{pH} 5.0,37^{\circ} \mathrm{C}\right) .(\mathrm{E})$ Time-dependent labeling of $\alpha$-amylase in complex biological samples with ABP 1c (pH 5.0, $\left.37^{\circ} \mathrm{C}\right)$. (F) Competitive ABPP on amylases in extracts from human saliva (HS), mouse pancreas (MP), and mouse salivary gland (MSG), offset against Western blot detection of amylase abundance using an anti-amylase antibody.

ABPs $\mathbf{1 c}, \mathbf{2 b}$, and $\mathbf{2 c}$ in hand, we first investigated their labeling efficiency and specificity toward recombinant human saliva $\alpha$ amylase (type XIII-A, HSA). Kinetic analysis for inactivation of Taka-amylase revealed the parent inhibitors $\mathbf{1 a}, \mathbf{1} \mathbf{b}$, and $\mathbf{2} \mathbf{a}$ as slow enzyme binders. Thus, recombinant $\alpha$-amylase was incubated with ABPs $\mathbf{1 c}, \mathbf{2 b}$, or $\mathbf{2 c}$ at two quite high concentrations $\left(100 \mu \mathrm{M}\right.$ or $\left.10 \mu \mathrm{M}, 1 \mathrm{~h}, 37^{\circ} \mathrm{C}, \mathrm{pH} 7\right)$. As shown in Figure 4A, HSA was effectively labeled by epoxidebased ABP 1c, while the labeling potency of aziridine-based $\mathrm{ABPs} \mathbf{2} \mathbf{b}$ and $\mathbf{2 c}$ was dramatically reduced, and only very weak bands were observed even at $100 \mu \mathrm{M}$ probe concentrations. In accordance with that of kinetic studies, the epoxide inhibitor $\mathbf{1 b}$ is much more potent than aziridine inhibitor $\mathbf{2 a}$. This observation is supported by the X-ray structure analysis of inhibitor-enzyme complexes, which indicates that interactions between the -3 subsite in $\alpha$-amylase active sites and the O4' substituent may contribute to the initial binding of $\mathbf{1 b}$ and the resulting increased inhibition potency while the alkylation of aziridine warhead in $\mathbf{2 a}$ is not preferred during enzyme binding.

Activity-Based Protein Profiling of Retaining $\alpha$ Amylases in Complex Biological Samples. As the next research objective, we attempted to visualize $\alpha$-amylases in concentrated human saliva and lysates from mouse pancreas and salivary gland with $\mathrm{ABP}$ 1c. As shown in Figure 4B, ABP 1c labeled a distinct band at $\sim 57 \mathrm{kDa}$, corresponding to the molecular weight of HSA. ${ }^{42}$ The same band was also observed in mouse pancreas lysates where significant labeling appeared at $25 \mu \mathrm{M}\left(2 \mathrm{~h}, 3{ }^{\circ} \mathrm{C}, \mathrm{pH} 7\right)$, while at higher probe concentrations background fluorescence was observed. Interestingly, labeling in mouse salivary gland lysates with 1c showed two clear bands, not only the one at $\sim 57 \mathrm{kDa}$ but also a slightly stronger band at $\sim 70 \mathrm{kDa}$. Next, the $\mathrm{pH}$ dependence of labeling was determined (Figure 4C). ABP 1c exhibits a similar $\mathrm{pH}$-dependent activity toward $\alpha$-amylase (at the time unknown $\sim 57 \mathrm{kDa}$ band) in these three biological samples, and the optimal $\mathrm{pH}$ for labeling is determined at 5.0, different from the reported neutral $\mathrm{pH}$ optimum in $\mathrm{HPA}^{21}$ and $\mathrm{HSA}^{42}$ activity. Of note, in mouse salivary gland lysates, the band at $\sim 70 \mathrm{kDa}$ only appeared following labeling at $\mathrm{pH}$ ranging from 6.0 to 8.0 with optimal labeling observed at $\mathrm{pH}$ 7.5. Additionally, the efficiency and the rate of labeling of $\alpha$ amylase were further investigated under optimal $\mathrm{pH} 5.0$ (Figure 4D and Figure 4E). In these three samples, $\alpha$-amylase (the $\sim 57 \mathrm{kDa}$ band) was selectively labeled by $1 \mathrm{c}$ in a concentration- and time-dependent manner, consistent with the irreversible inhibition mechanism one would expect for the maltose cyclophellitols. 

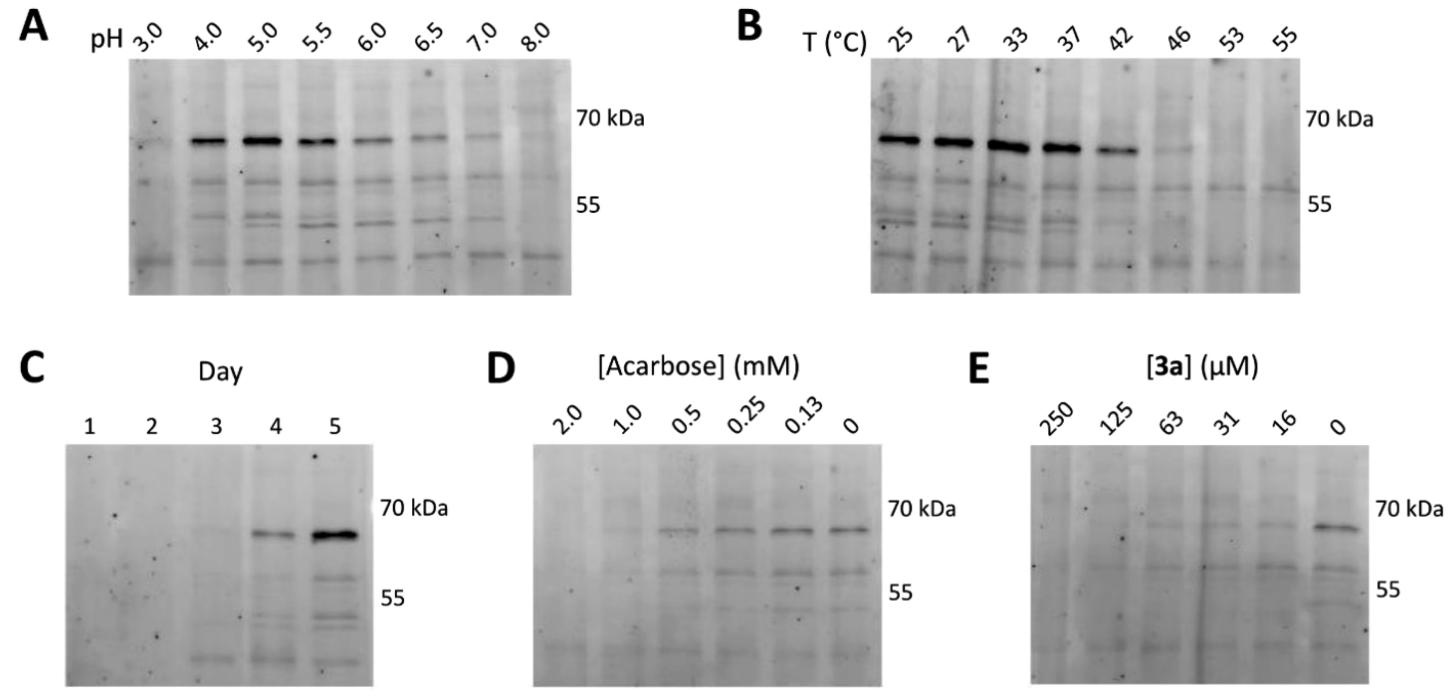

Figure 5. (A) Fluorescent labeling of day 5 A. nidulans secretome with ABP $1 \mathrm{c}$ at $\mathrm{pH} 3-8$ after incubation for $1 \mathrm{~h}$ at $37^{\circ} \mathrm{C}$. (B) Temperature dependent labeling of day 5 A. nidulans secretome with $\mathrm{ABP} 1 \mathrm{c}$ after incubation at $\mathrm{pH} 5.0$ for $1 \mathrm{~h}$ at $25-55^{\circ} \mathrm{C}$. (C) Fluorescent labeling of day $1-5$ A. nidulans secretomes with $\mathrm{ABP} 1 \mathrm{c}$ at $\mathrm{pH} 5.0$ after incubation for $1 \mathrm{~h}$ at $37^{\circ} \mathrm{C}$. (D) Competitive ABPP of day 5 A. nidulans secretome with acarbose. The secretome was preincubated with acarbose at varying concentrations $\left(30 \mathrm{~min}, \mathrm{pH} 5.0,37^{\circ} \mathrm{C}\right)$ prior to labeling with $\mathrm{ABP} 1 \mathrm{c}(67.5$ $\mu \mathrm{M}, 1 \mathrm{~h}, \mathrm{pH} 5.0,37^{\circ} \mathrm{C}$ ). (E) Competitive ABPP of day 5 A. nidulans secretome with $3 \mathrm{a}$. The secretome was preincubated with $3 \mathrm{a}$ at varying concentrations $\left(30 \mathrm{~min}, \mathrm{pH} 5.0,37^{\circ} \mathrm{C}\right)$ prior to labeling with $\mathrm{ABP} 1 \mathrm{c}\left(67.5 \mu \mathrm{M}, 1 \mathrm{~h}, \mathrm{pH} 5.0,37^{\circ} \mathrm{C}\right)$.

Having established that amylase activities could be visualized in extracts from human saliva, murine pancreas, and murine salivary glands, competitive ABPP (cABPP) experiments were performed to see whether these activities could be negated by inclusion of a nontagged inhibitor. Preincubation of biological samples with inhibitor 1d followed by labeling with Cy5 ABP 1c resulted in a decrease of fluorescent signals similar to denaturation of the samples with $2 \%$ SDS (Figure 4F). After fluorescent imaging, proteins were transferred to a polyvinylidene fluoride (PVDF) membrane for Western blot analysis with an anti-amylase antibody. The observed fluorescent bands and chemiluminescence bands match well where no inhibitor is included, with the chemiluminescence bands remaining equal in intensity where the $A B P$ signal decreases in an inhibitor-dependent fashion, confirming that ABP 1c labeled amylase. CABPP assays were also performed with inhibitors $\mathbf{1 a}$ and $\mathbf{1 b}$ in human saliva (Figure S5). Compared with $\mathbf{1 d}$, the inhibition potency of these two was reduced and only minor competition was observed with "untagged" 1a at the highest concentration applied $(100 \mu \mathrm{M})$, further indicating that alkylation of the $\mathrm{O} 4^{\prime}$ position of the epoxide-based inhibitor may improve its inhibition potency.

ABPP of Fungal Secretomes. The probes developed herein can also be applied to monitor the production of amylases by biotechnologically relevant fungi. Secretomes from the saprophytic ascomycete Aspergillus nidulans grown on various starches have previously been shown to contain a complex mixture of amylases, glucosidases, and oxidative enzymes. ${ }^{43}$ We performed ABPP of secretomes from a time course of $A$. nidulans strain FGSC A4 growth in minimal media supplemented with $1 \%$ wheat starch as a carbon source. Secretome samples were taken daily over a 5-day period, and the fluorescent $\mathrm{Cy} 5 \mathrm{ABP}$ 1c was incubated with these secretome samples to reveal a complex pattern of fluorescent bands that could first be detected starting by day 3. The intensity of amylase bands increased after day 3 with a maximum intensity at day 5 (Figure 5C).
Conventional industrial starch hydrolysis relies on enzymes that are both thermostable and acid tolerant. ${ }^{44,45}$ Both of these metrics can be measured directly from the secretome using $\mathrm{ABPP}$, capturing these parameters in the native enzyme environment. Labeling of the day 5 secretome in the presence of Mcllvaine buffers at $\mathrm{pH}$ between 3.0 and 8.0 revealed $\mathrm{pH}$ dependent labeling patterns (Figure 5A). The most intense band (observed at $\sim 66 \mathrm{kDa}$ ) was labeled between $\mathrm{pH} 4.0$ and $\mathrm{pH} 7.0$, while the bands appearing at $\sim 52$ and $\sim 48 \mathrm{kDa}$ were constrained to labeling between 4.0 and 5.5 and 5.0-7.0, respectively. We next assessed the temperature-dependent labeling of the day $5 \mathrm{~A}$. nidulans secretome at $\mathrm{pH} 5.0$ and at temperatures between 25 and $55^{\circ} \mathrm{C}$ (Figure 5B). Within this range the bands at $\sim 66, \sim 52$, and $\sim 48 \mathrm{kDa}$ all showed temperature dependent labeling, with labeling efficiency decreased above $37{ }^{\circ} \mathrm{C}$, presumably due to denaturation of the corresponding proteins at this temperature. Conversely the bands at $\sim 58 \mathrm{kDa}$ and $\sim 44 \mathrm{kDa}$ remained present at the highest temperature tested.

We next used cABPP to show the sensitivity of enzyme labeling to both competitive and covalent inhibitors (Figure $5 \mathrm{D}, \mathrm{E})$. As mentioned above, cABPP allows for the identification of active enzyme inhibitors, without the need for purification and even if the identity of the active enzyme is unknown. ${ }^{46,47}$ Preincubation of secretomes for $30 \mathrm{~min}$ with either acarbose or 3a prior to labeling with ABP $1 \mathrm{c}$ resulted in decreased labeling of specific bands in a concentration dependent manner. Enzyme bands at $~ 66, \sim 58, \sim 52$, and $\sim 48 \mathrm{kDa}$ were all inhibited by either acarbose or $3 \mathrm{a}$, while the band at $44 \mathrm{kDa}$ appeared to be insensitive to these $\alpha$-amylase inhibitors.

Identification of ABP Labeled Bands. To further determine the specificity of the developed ABPs, we have analyzed the ABP-labeled proteins in human saliva sample. For this purpose, we incubated human saliva sample with biotinylated $A B P$ 1d, a no probe control (DMSO only), or a competitor-inhibited control (first treatment with $\mathbf{1 b}$ ). ABP 
1d-labeled proteins were enriched by using magnetic streptavidin beads. After on-bead tryptic digestion, the resulting peptides were analyzed by LC-MS/MS and matched against the human UniProt database, using the Mascot search engine as previously described. ${ }^{48}$ As expected, AMY1A (P04745) was clearly abundant in the ABP 1d pulldown experiment (Table S2). Other proteins with high scores were background proteins such as enolase standard and keratin contaminations. Pretreatment of the saliva sample with inhibitor $\mathbf{1 b}$ caused a significant loss of AMY1A peptide abundance, and almost no AMY1A was found in the untreated control. These results demonstrate AMY1A in human saliva sample can be selectively labeled and identified via biotinylated ABP 1d.

On the basis of the known content of $A$. nidulans secretome, ${ }^{43}$ we tentatively assigned the most prominent $\sim 66 \mathrm{kDa}$ band labeled with $1 \mathrm{c}$ as the mature form of $\alpha$-amylase AmyB (ANIA_03402); see Table S4 for list of mature $\alpha$ amylase molecular masses. The two minor bands at $\sim 52$ and $\sim 48 \mathrm{kDa}$ were also tentatively assigned as AmyA (ANIA_03388) and AmyF (ANIA_0201) $\alpha$-amylases, respectively. As the wheat starch grown secretome of $A$. nidulans only contains three amylases, ${ }^{43}$ the final two minor bands could not be confidently assigned. We however speculate that these are proteins that are highly abundant in the secretome.

To identify the labeled enzymes in the $A$. nidulans secretome, we also performed an activity-based protein pulldown. The day 5 secretome was treated with either the biotinylated $A B P$ 1d or an equivalent volume of DMSO, and then a pulldown was performed using streptavidin beads, followed by an on bead tryptic digest and LC-MS/MS analysis. All three amylases from the $A$. nidulans secretome (AmyA, AmyF, and AmyB) were detected at elevated levels in the probe 1d-treated samples relative to the negative control and total secretome, confirming our initial assignment of the major and two minor bands observed by in-gel fluorescence (Table S3). We also detected $\mathrm{ChiB}$, an endochitanase, and $\mathrm{AgdB}$, an $\alpha$-glucosidase, both of which are highly abundant in the secretome (Table S3). The molecular weights of the detected amylases match well with the labeled bands seen from ABPP with probe 1c. Furthermore, these results suggest the identities of the minor bands seen at 44 and $58 \mathrm{kDa}$ may belong respectively to $\mathrm{CbiB}$ and $\mathrm{AgdB}$, the former, which is proteolytically processed from its $108 \mathrm{kDa}$ form to a heterodimer with the catalytic protomer, having a $58 \mathrm{kDa}$ molecular weight. ${ }^{49}$

\section{CONCLUSION}

We have synthesized a panel of maltobiose-configured epicyclophellitol derivatives as mechanism-based covalent inhibitors and ABPs for retaining $\alpha$-amylases. Kinetic studies of the inhibition of Taka-amylase revealed that the cyclosulfate warhead (3a) is the most potent, compared with its epoxide and aziridine counterparts (1a and $\mathbf{2 a}$ ). As well, alkylation of $\mathrm{O} 4^{\prime}$ of the nonreducing end sugar in $\mathbf{1 a}$ led to compound $\mathbf{1 b}$ that inhibits $\alpha$-amylase up to 10 -fold more potently than the parent compound. Compound conformations can strongly influence the inhibitory potencies and selectivities of cyclophellitol analogues. Our X-ray studies have shown that both epoxide and cyclosulfate-based inhibitors bind to the active site nucleophilic residue of Taka-amylase in a ${ }^{4} \mathrm{C}_{1}$ chair conformation, while the structure of aziridine $2 \mathrm{a}$ complex was found in an unprecedented $\mathrm{E}_{3}$ conformation, likely due to the presence of the aziridine alkyl-chain, which might account for its lower potency. The inability of fluorescent ABPs $\mathbf{2 b}$ and $2 c$ to modify recombinant human saliva $\alpha$-amylase further indicated that substituted aziridines are not accepted by the tested amylases. In contrast, epoxide-based ABP 1c selectively labels $\alpha$-amylases in human saliva and mice tissue in a concentration- and time-dependent manner, with optimum labeling at $\mathrm{pH}$ 5.0. In addition, it can also effectively detect $\alpha$ amylases in fungal secretomes and allow easy readout of $\mathrm{pH}$ and temperature dependence and susceptibility to inhibitors. Looking ahead, we speculate that installation of reporter entities at $\mathrm{O}^{\prime}$ ' of the nonreducing end sugar of cyclosulfatebased inhibitor 3a would yield more potent ABPs based on kinetic and crystallographic studies. In conclusion, our maltobiose epi-cyclophellitol ABPs allow activity-based profiling of $\alpha$-amylases in complex biological samples and may find use in the discovery of new and effective human amylase inhibitors that may have potential as therapeutic reagents for the treatment of type 2 diabetes and in the discovery of new microbial amylases with potentially advantageous properties for biotechnological application.

\section{ASSOCIATED CONTENT}

\section{Supporting Information}

The Supporting Information is available free of charge on the ACS Publications Web site at DOI: (PDF) (XLSX) The Supporting Information is available free of charge at https:// pubs.acs.org/doi/10.1021/jacs.0c13059.

Experimental data and procedures, crystallographic data, and synthesis (PDF)

Proteomics data (XLSX)

Spectral counts and raw abundance (XLSX)

\section{AUTHOR INFORMATION}

\section{Corresponding Authors}

Gideon J. Davies - Department of Chemistry, York Structural Biology Laboratory, University of York, York YO10 5DD, United Kingdom; 이이.org/0000-0002-7343-776X; Email: gideon.davies@york.ac.uk

Herman S. Overkleeft - Department of Bioorganic Synthesis, Leiden University, 2333 CC Leiden, The Netherlands; ○ orcid.org/0000-0001-6976-7005; Email: h.s.overkleeft@ lic.leidenuniv.nl

\section{Authors}

Yurong Chen - Department of Bioorganic Synthesis, Leiden University, 2333 CC Leiden, The Netherlands; (1) orcid.org/ 0000-0001-5358-2989

Zachary Armstrong - Department of Chemistry, York Structural Biology Laboratory, University of York, York YO10 5DD, United Kingdom; 이이이.org/0000-00024086-2946

Marta Artola - Department of Bioorganic Synthesis and Department of Medical Biochemistry, Leiden Institute of Chemistry, Leiden University, 2333 CC Leiden, The Netherlands; (1) orcid.org/0000-0002-3051-3902

Bogdan I. Florea - Department of Bioorganic Synthesis, Leiden University, 2333 CC Leiden, The Netherlands; (1) orcid.org/0000-0001-7114-2266

Chi-Lin Kuo - Department of Medical Biochemistry, Leiden Institute of Chemistry, Leiden University, 2333 CC Leiden, The Netherlands; O orcid.org/0000-0003-3748-5008 
Casper de Boer - Department of Bioorganic Synthesis, Leiden University, 2333 CC Leiden, The Netherlands; (1) orcid.org/ 0000-0002-0869-6060

Mikkel S. Rasmussen - Department of Biotechnology and Biomedicine, Technical University of Denmark, $2800 \mathrm{Kgs}$. Lyngby, Denmark

Maher Abou Hachem - Department of Biotechnology and Biomedicine, Technical University of Denmark, $2800 \mathrm{Kgs}$. Lyngby, Denmark; 이잉.org/0000-0001-8250-1842

Gijsbert A. van der Marel - Department of Bioorganic Synthesis, Leiden University, 2333 CC Leiden, The Netherlands

Jeroen D. C. Codée - Department of Bioorganic Synthesis, Leiden University, 2333 CC Leiden, The Netherlands; () orcid.org/0000-0003-3531-2138

Johannes M. F. G. Aerts - Department of Medical Biochemistry, Leiden Institute of Chemistry, Leiden University, 2333 CC Leiden, The Netherlands; 이이.org/ 0000-0001-8168-2565

Complete contact information is available at:

https://pubs.acs.org/10.1021/jacs.0c13059

\section{Author Contributions}

Y.C. and Z.A. contributed equally to this paper.

\section{Notes}

The authors declare no competing financial interest.

\section{ACKNOWLEDGMENTS}

We thank the China Scholarship Council (CSC, Ph.D. Grant to Y.C.), the Royal Society (Ken Murray Research Professorship to G.J.D.), and the Biotechnology and Biological Sciences Research Council (BBSRC) (Grant BB/R001162/1 to G.J.D. and Z.A.). We also thank the Novo Nordisk Foundation Postdoc grant within the Biotechnology-Based Synthesis and Production Research program (Grant NNF17OC0025642). We thank the Diamond Light Source for access to beamlines i04 and i03 (Proposal Numbers mx-18598-21 and mx-1859825) that contributed to the results presented here and Johan Turkenburg and Sam Hart for coordinating data collection.

\section{REFERENCES}

(1) Lombard, V.; Golaconda Ramulu, H.; Drula, E.; Coutinho, P. M.; Henrissat, B. The carbohydrate-active enzymes database (CAZy) in 2013. Nucleic Acids Res. 2014, 42 (D1), D490-D495.

(2) Huang, N.; Stebbins, G. L.; Rodriguez, R. L. Classification and evolution of $\alpha$-amylase genes in plants. Proc. Natl. Acad. Sci. U. S. A. 1992, 89, 7526-7530.

(3) Brayer, G. D.; Luo, Y.; Withers, S. G. The structure of human pancreatic a-amylase at $1.8 \AA$ resolution and comparisons with related enzymes. Protein Sci. 1995, 4, 1730-1742.

(4) Gupta, R.; Gigras, P.; Mohapatra, H.; Goswami, V. K.; Chauhan, B. Microbial $\alpha$-amylases: a biotechnological perspective. Process Biochem. 2003, 38 (11), 1599-1616.

(5) Zechel, D. L.; Withers, S. G. Glycosidase mechanisms: Anatomy of a finely tuned catalyst. Acc. Chem. Res. 2000, 33 (1), 11-18.

(6) Nakazawa, Y.; Wang, Y. J. Acid hydrolysis of native and annealed starches and branch-structure of their Naegeli dextrins. Carbohydr. Res. 2003, 338 (24), 2871-2882.

(7) Wang, S.; Copeland, L. Effect of acid hydrolysis on starch structure and functionality: a review. Crit. Rev. Food Sci. Nutr. 2015, 55 (8), 1081-1097.

(8) Kirk, O.; Borchert, T. V.; Fuglsang, C. C. Industrial enzyme applications. Curr. Opin. Biotechnol. 2002, 13 (4), 345-351.
(9) van der Maarel, M. J. E. C.; van der Veen, B.; Uitdehaag, J. C. M.; Leemhuis, H.; Dijkhuizen, L Properties and applications of starchconverting enzymes of the $\alpha$-amylase family. J. Biotechnol. 2002, 94, $137-155$.

(10) Souza, P. M. d.; Magalhães, P. d. O. e. Application of microbial $\alpha$-amylase in industry - a review. Braz. J. Microbiol. 2010, 41, 850861.

(11) Sundarram, A.; Murthy, T. P. K. $\alpha$-Amylase production and applications: a review. J. Appl. Environ. Microbiol. 2014, 2, 166-175.

(12) Hmidet, N.; El-Hadj Ali, N.; Haddar, A.; Kanoun, S.; Alya, S.K.; Nasri, M. Alkaline proteases and thermostable $\alpha$-amylase coproduced by Bacillus licheniformis NH1: Characterization and potential application as detergent additive. Biochem. Eng. J. 2009, 47 (1-3), 71-79.

(13) Rana, N.; Walia, A.; Gaur, A. $\alpha$-Amylases from microbial sources and its potential applications in various industries. Natl. Acad. Sci. Lett. 2013, 36 (1), 9-17.

(14) Mooradian, A. D.; Thurman, J. E. Drug therapy of postprandial hyperglycaemia. Drugs 1999, 57 (1), 19-29.

(15) Scott, L. J.; Spencer, C. M. Miglitol: a review of its therapeutic potential in type 2 diabetes mellitus. Drugs 2000, 59, 521-549.

(16) Chiasson, J.-L.; Josse, R. G.; Gomis, R.; Hanefeld, M.; Karasik, A.; Laakso, M. Acarbose for prevention of type 2 diabetes mellitus: the STOP-NIDDM randomised trial. Lancet 2002, 359 (9323), 2072-2077.

(17) Li, C.; Begum, A.; Numao, S.; Park, K. H.; Withers, S. G.; Brayer, G. D. Acarbose rearrangement mechanism implied by the kinetic and structural analysis of human pancreatic $\alpha$-amylase in complex with analogues and their elongated counterparts. Biochemistry 2005, 44, 3347-3357.

(18) Nahoum, V.; Roux, G.; Anton, V.; RougÉ, P.; Puigserver, A.; Bischoff, H.; Henrissat, B.; Payan, F. Crystal structures of human pancreatic $\alpha$-amylase in complex with carbohydrate and proteinaceous inhibitors. Biochem. J. 2000, 346 (1), 210-208.

(19) Tarling, C. A.; Woods, K.; Zhang, R.; Brastianos, H. C.; Brayer, G. D.; Andersen, R. J.; Withers, S. G. The search for novel human pancreatic alpha-amylase inhibitors: high-throughput screening of terrestrial and marine natural product extracts. ChemBioChem 2008, 9 (3), 433-438.

(20) Williams, L. K.; Zhang, X.; Caner, S.; Tysoe, C.; Nguyen, N. T.; Wicki, J.; Williams, D. E.; Coleman, J.; McNeill, J. H.; Yuen, V.; Andersen, R. J.; Withers, S. G.; Brayer, G. D. The amylase inhibitor montbretin A reveals a new glycosidase inhibition motif. Nat. Chem. Biol. 2015, 11 (9), 691-696.

(21) Braun, C.; Brayer, G. D.; Withers, S. G. Mechanism-based inhibition of yeast $\alpha$-glucosidase and human pancreatic $\alpha$-amylase by a new class of inhibitors. J. Biol. Chem. 1995, 270, 26778-26781.

(22) Zhang, R.; McCarter, J. D.; Braun, C.; Yeung, W.; Brayer, G. D.; Withers, S. G. Synthesis and testing of 2-deoxy-2,2-dihaloglycosides as mechanism-based inhibitors of $\alpha$-Glycosidases. J. Org. Chem. 2008, 73, 3070-3077.

(23) Zhang, R.; Li, C.; Williams, L. K.; Rempel, B. P.; Brayer, G. D.; Withers, S. G. Directed "in situ" inhibitor elongation as a strategy to structurally characterize the covalent glycosyl-enzyme intermediate of human pancreatic alpha-amylase. Biochemistry 2009, 48 (45), 1075210764.

(24) Caner, S.; Zhang, X.; Jiang, J.; Chen, H. M.; Nguyen, N. T.; Overkleeft, H.; Brayer, G. D.; Withers, S. G. Glucosyl epicyclophellitol allows mechanism-based inactivation and structural analysis of human pancreatic alpha-amylase. FEBS Lett. 2016, 590 (8), $1143-1151$.

(25) Cravatt, B. F.; Wright, A. T.; Kozarich, J. W. Activity-based protein profiling: from enzyme chemistry to proteomic chemistry. Annu. Rev. Biochem. 2008, 77, 383-414.

(26) Willems, L. I.; Overkleeft, H. S.; van Kasteren, S. I. Current developments in activity-based protein profiling. Bioconjugate Chem. 2014, 25 (7), 1181-1191.

(27) Atsumi, S.; Umezawa, K.; Iinuma, H.; Naganawa, H.; Nakamura, H.; Iitaka, Y.; Takeuchi, T. Production, isolation and 
structure determination of a novel beta-glucosidase inhibitor, cyclophellitol, from Phellinus sp. J. Antibiot. 1990, 43 (1), 49-53.

(28) Jiang, J.; Kallemeijn, W. W.; Wright, D. W.; van den Nieuwendijk, A.; Rohde, V. C.; Folch, E. C.; van den Elst, H.; Florea, B. I.; Scheij, S.; Donker-Koopman, W. E.; Verhoek, M.; Li, N.; Schurmann, M.; Mink, D.; Boot, R. G.; Codée, J. D. C.; van der Marel, G. A.; Davies, G. J.; Aerts, J.; Overkleeft, H. S. In vitro and in vivo comparative and competitive activity-based protein profiling of GH29 alpha-1-fucosidases. Chem. Sci. 2015, 6 (5), 2782-2789.

(29) Willems, L. I.; Beenakker, T. J.; Murray, B.; Scheij, S.; Kallemeijn, W. W.; Boot, R. G.; Verhoek, M.; Donker-Koopman, W. E.; Ferraz, M. J.; van Rijssel, E. R.; Florea, B. I.; Codée, J. D.; van der Marel, G. A.; Aerts, J. M.; Overkleeft, H. S. Potent and selective activity-based probes for $\mathrm{GH} 27$ human retaining alpha-galactosidases. J. Am. Chem. Soc. 2014, 136 (33), 11622-11625.

(30) Jiang, J.; Kuo, C. L.; Wu, L.; Franke, C.; Kallemeijn, W. W.; Florea, B. I.; van Meel, E.; van der Marel, G. A.; Codée, J. D.; Boot, R. G.; Davies, G. J.; Overkleeft, H. S.; Aerts, J. M. Detection of active mammalian GH31 alpha-glucosidases in health and disease using inclass, broad-spectrum activity-based probes. ACS Cent. Sci. 2016, 2 (5), 351-358.

(31) Wu, L.; Jiang, J.; Jin, Y.; Kallemeijn, W. W.; Kuo, C.-L.; Artola, M.; Dai, W.; van Elk, C.; van Eijk, M.; van der Marel, G. A.; Codée, J. D. C.; Florea, B. I.; Aerts, J. M. F. G.; Overkleeft, H. S.; Davies, G. J. Activity-based probes for functional interrogation of retaining $\beta$ glucuronidases. Nat. Chem. Biol. 2017, 13, 867-873.

(32) McGregor, N. G. S.; Artola, M.; Nin-Hill, A.; Linzel, D.; Haon, M.; Reijngoud, J.; Ram, A.; Rosso, M. N.; van der Marel, G. A.; Codée, J. D. C.; van Wezel, G. P.; Berrin, J. G.; Rovira, C.; Overkleeft, H. S.; Davies, G. J. Rational Design of Mechanism-based inhibitors and activity-based probes for the identification of retaining alpha-Larabinofuranosidases. J. Am. Chem. Soc. 2020, 142 (10), 4648-4662.

(33) Schröder, S. P.; de Boer, C.; McGregor, N. G. S.; Rowland, R. J.; Moroz, O.; Blagova, E.; Reijngoud, J.; Arentshorst, M.; Osborn, D.; Morant, M. D.; Abbate, E.; Stringer, M. A.; Krogh, K.; Raich, L.; Rovira, C.; Berrin, J. G.; van Wezel, G. P.; Ram, A. F. J.; Florea, B. I.; van der Marel, G. A.; Codée, J. D. C.; Wilson, K. S.; Wu, L.; Davies, G. J.; Overkleeft, H. S. Dynamic and functional profiling of xylandegrading enzymes in Aspergillus secretomes using activity-based probes. ACS Cent. Sci. 2019, 5 (6), 1067-1078.

(34) de Boer, C.; McGregor, N. G. S.; Peterse, E.; Schröder, S. P.; Florea, B. I.; Jiang, J.; Reijngoud, J.; Ram, A. F. J.; van Wezel, G. P.; van der Marel, G. A.; Codée, J. D. C.; Overkleeft, H. S.; Davies, G. J. Glycosylated cyclophellitol-derived activity-based probes and inhibitors for cellulases. RSC Chemical Biology 2020, 1 (3), 148-155.

(35) Artola, M.; Wu, L.; Ferraz, M. J.; Kuo, C. L.; Raich, L.; Breen, I. Z.; Offen, W. A.; Codée, J. D. C.; van der Marel, G. A.; Rovira, C.; Aerts, J.; Davies, G. J.; Overkleeft, H. S. 1,6-Cyclophellitol cyclosulfates: A new class of irreversible glycosidase inhibitor. ACS Cent. Sci. 2017, 3 (7), 784--793.

(36) Wang, L.; Overkleeft, H. S.; van der Marel, G. A.; Codée, J. D. C. Reagent controlled stereoselective synthesis of alpha-glucans. J. Am. Chem. Soc. 2018, 140 (13), 4632-4638.

(37) Sherman, H. C.; Kendall, E. C.; Clark, E. D. Studies on Amylases. I. An examination of methods for the determination of diastatic power. J. Am. Chem. Soc. 1910, 32 (9), 1073-1086.

(38) Takamine, J. Diastatic substances from fungus growths. J. Soc. Chem. Ind. 1898, 17 (2), 118-120.

(39) Kato, S.; Shimizu-Ibuka, A.; Mura, K.; Takeuchi, A.; Tokue, C.; Arai, S. Molecular cloning and characterization of an $\alpha$-amylase from Pichia burtonii15-1. Biosci., Biotechnol., Biochem. 2007, 71 (12), 3007-3013.

(40) Alonso-Gil, S.; Coines, J.; André, I.; Rovira, C. Conformational itinerary of sucrose during hydrolysis by retaining amylosucrase. Front. Chem. 2019, 7, 269.

(41) Brzozowski, A. M.; Davies, G. J. Structure of the Aspergillus oryzae $\alpha$-amylase complexed with the inhibitor acarbose at $2.0 \AA$ resolution. Biochemistry 1997, 36 (36), 10837-10845.
(42) Fisher, S. Z.; Govindasamy, L.; Tu, C.; Agbandje-McKenna, M.; Silverman, D. N.; Rajaniemi, H. J.; McKenna, R. Structure of human salivary alpha-amylase crystallized in a C-centered monoclinic space group. Acta Crystallogr., Sect. F: Struct. Biol. Cryst. Commun. 2006, 62 (2), 88-93.

(43) Nekiunaite, L.; Arntzen, M. O.; Svensson, B.; Vaaje-Kolstad, G.; Abou Hachem, M. Lytic polysaccharide monooxygenases and other oxidative enzymes are abundantly secreted by Aspergillus nidulans grown on different starches. Biotechnol. Biofuels 2016, 9 (1), 187-202.

(44) Parashar, D.; Satyanarayana, T. An insight into ameliorating production, catalytic efficiency, thermostability and starch saccharification of acid-stable alpha-amylases from acidophiles. Front. Bioeng. Biotechnol. 2018, 6, 125.

(45) Crabb, W. D.; Mitchinson, C. Enzymes involved in theprocessing of starch to sugars. Trends Biotechnol. 1997, 15, 349352.

(46) Wu, L.; Armstrong, Z.; Schröder, S. P.; de Boer, C.; Artola, M.; Aerts, J. M.; Overkleeft, H. S.; Davies, G. J. An overview of activitybased probes for glycosidases. Curr. Opin. Chem. Biol. 2019, 53, 2536.

(47) Armstrong, Z.; Kuo, C. L.; Lahav, D.; Liu, B.; Johnson, R.; Beenakker, T. J. M.; de Boer, C.; Wong, C. S.; van Rijssel, E. R.; Debets, M. F.; Florea, B. I.; Hissink, C.; Boot, R. G.; Geurink, P. P.; Ovaa, H.; van der Stelt, M.; van der Marel, G. M.; Codée, J. D. C.; Aerts, J.; Wu, L.; Overkleeft, H. S.; Davies, G. J. Manno-epicyclophellitols enable activity-based protein profiling of human alphamannosidases and discovery of new Golgi mannosidase II inhibitors. J. Am. Chem. Soc. 2020, 142 (30), 13021-13029.

(48) Kuharev, J.; Navarro, P.; Distler, U.; Jahn, O.; Tenzer, S. Indepth evaluation of software tools for data-independent acquisitionbased label-free quantification. Proteomics 2015, 15 (18), 3140-3151.

(49) Kato, N.; Suyama, S.; Shirokane, M.; Kato, M.; Kobayashi, T.; Tsukagoshi, N. Novel alpha-glucosidase from Aspergillus nidulans with strong transglycosylation activity. Appl. Environ. Microbiol. 2002, 68 (3), $1250-1256$. 